\title{
Computer Mediated Communications and Religion: An Evolutionary Primer
}

\author{
Shu-Chen Tsai \\ University of Toronto, Toronto, Canada \\ Email: shuchen6688@hotmail.com
}

Received 2 January 2015; accepted 20 January 2015; published 23 January 2015

Copyright (C) 2015 by author and Scientific Research Publishing Inc.

This work is licensed under the Creative Commons Attribution International License (CC BY). http://creativecommons.org/licenses/by/4.0/

c) (i) Open Access

\begin{abstract}
The research examines the field of Computer Mediated Communications and religion from an evolutionary perspective by tracing five subjectively selected developments in this field of research and, in so doing, offers a brief primer by which to navigate the morass of research regarding this topic.
\end{abstract}

\section{Keywords}

\section{Computer Mediated Communications, Internet Religion, Religion and Technology}

For many signing on to the Internet is a transformative act. In their eyes the web is more than just a global tapestry of personal computers. It is a vast cathedral of the mind, a place where ideas about God and religion can resonate, where faith can be shaped and defined by a collective spirit.

[1] (Chama, 1996, p. 57)

\section{Introduction}

As a religious layperson and a computer novice, I decided to take a university course called Computer Mediated Communications in order to learn how religion has been impacted by the communication revolution incited by the invention of the computer. The breadth of our readings in the course reveals that computer mediated communications (CMCs) now permeate virtually every aspect of modern human culture. From politics to economics to education to social movements to capitalism to the philosophy of technology the tentacles of CMCs appeared ubiquitous. However, as we made our way though the course examining one use after another of CMCs, one major social institution became conspicuous to me by its absence; the institution of religion. Thinking I must have encountered a virgin territory as yet untouched by the computer, I determined to take the occasion of the last assignment of the course to investigate the issue. I would research CMCs in religion generally and CMCs in 
Christianity specifically.

Very soon in my research I began to be troubled. Contrary to my expectations of virgin territory, I encountered instead what appeared to be a wholly unmanageable amount of research regarding the topic. Notwithstanding the absence of any focus on religion in my class, it apparently was an issue that was treated frequently in the literature. The fecundity of only one researcher, Heidi Campbell, would require weeks to analyze. My attitude went from "wonder" at how religion and CMCs could be completely overlooked to "wondering" how to make sense of a research field that had been so looked over.

To order my research of the field, I determined to approach it from an evolutionary perspective. No one, of course, can know in real time which mutations will bear future fruit but I have chosen five evolutionary developmental "sprouts" in the research literature of religion and CMCs from which to navigate the morass of information available on the topic in a relative short space. They are central issues/themes regarding the recent development (evolution) of religious use of CMCs that I deem important and I have reviewed them within the context of the literature that I found best suited to illustrate them. In doing so, I do not purport to be comprehensive in my review of the literature. Instead, as one traversing a shallow but wide body of water and stepping on the best rocks to avoid getting wet, I relate my own personal sense of where the apparent random morass of information regarding religion and CMC may be headed and, in doing so, hope to offer the reader a limited conceptual primer of the area.

\section{Theme: Religious Attitudes toward Technology—The Secularization Thesis}

[2] Campbell (2005) argues that in the past religion has both fueled and shaped the historical development of technology. Citing both the printing press and its relation to the Protestant reformation as well as the influence of Islam in the development of astronomy and cartography she makes the case that historically religion has been an important determinate of technology. However, she laments that now religion is often overlooked in studies of technology saying, "This disregard is often linked to the 'secularization of society' thesis, according to which religion has lost its central role in society and therefore its importance. Religion is described as being in decline and therefore increasingly irrelevant in the public sphere, especially in Western societies [2] (Campbell, p. 310)."

Every since the enlightenment the contrast between faith (religion) and science (technology) appears to have been drawn in increasingly sharper terms. According to Kong (2001), during the last half of the 20th century one of the greatest refrains of the social sciences of the western world has been the secularization thesis. It is, as explained by Kong (2001), that "modernity has led to the substitution of religious traditions with rationalism, scientism and individualism (p. 404) [3].”

In evaluating the present relevance of the secularization thesis, Campbell (2005) traces the growth of religious use of CMC technology since the 1990s arguing that "(w)hile religion occupies a different place in general society than it has in previous eras, there is a growing recognition that it plays an important, unspoken role in the lives of many communities" and further that " $(t) h e$ internet has provided religious practitioners with new ways to explore religious beliefs and experiences through a growing number of web sites, chat rooms, and e-mail discussion groups dedicated to a variety of faith-related issues (pp. 310-311) [2].”

Finally, she notes that at the beginning of the 21st century there is recognition in many sectors that understanding religion is vital for the global community, saying "This is especially so with the rise of religious fundamentalism worldwide within traditional religions [2] (Campbell, 2005, p. 313).”

As religious use of CMCs began to develop in the 1990s, Campbell (2005) [2] identified three attitudes typifying religious users toward the technology of the internet.

\subsection{Advocates}

Advocates viewed the use of the internet almost as an ideal form of communication; one where believers could speak freely as well as one that provided great access to information. To the advocates the internet is God-given to be used for God's purposes. Campbell points out that British researcher Patrick Dixon reflected this view in saying, "The internet world needs cyberchurch, not as a substitute for local church life, but as a vibrant electronic expression of the life found in the body of Christ found worldwide (Campbell, 2003, p. 216) [2].” Wilson (2000) echoes a similar theme in saying, "He is with us here in this moment of history, this information age, equipping us and empowering us for the creation of the internet church (p. 120) [4].” 


\subsection{Critics}

According to Campbell (2003), some users were both antagonistic and fearful toward the internet, "often portraying it as a de-humanizing medium, a threat to "real" community and communication." She notes that one observer viewed the internet in such stark terms as to exclaim we are going "towards the spiritual landscape of Genesis before the great flood where man creates his own universe with no god in it but himself." Campbell continued suggesting that the critics "evaluated the Internet not simply as a tool, but also as a conveyer of spiritual doctrines and ideas (p. 215) [5]” and as such that it potentially held danger for believers and their relationship with God and the church.

\subsection{Critical Friends}

Critical friendship reflected a middle ground between what Campbell (2003) calls the technophobes and technophiles described above. She describes it "as an attempt to reflect on both the advantages and the disadvantages offered by internet technology." She offers Denver Seminary theologian Douglas Groothuis as an example of this category quoting him as saying, "given the present tendency to worship technology, some negativity is necessary in order to bring some balance" but in also noting that "all technologies extensively alter human forms of life... our souls and our society" and suggesting that Christians must consider how technology "may affect our relationship with God as well as earthly lifestyle (p. 216) [5].” Campbell concludes by noting that it is this approach that today characterizes the attitude of most religious internet users today.

Notwithstanding Campbell's (2003) [5] assertion regarding the present popularity of the "critical friend” approach, I close this section with a quote from the 2002 Vatican document "The Church and Internet." As the largest single denomination of Christianity it demonstrates that practically speaking there remains a great deal of ambivalence and tension in its stance regarding the internet and that the stance of "critical friend" has not yet completely carried the day:

Virtual reality is no substitute for the Real Presence of Christ in the Eucharist, the sacramental reality of the other sacraments, and shared worship in a flesh-and-blood human community. There are no sacraments on the Internet; and even the religious experiences possible there by the grace of God are insufficient apart from real-world interaction with other persons of faith...pastoral planning should consider how to lead people from cyberspace to true community and how, through teaching and catechesis, the Internet might subsequently be used to sustain and enrich them in their Christian commitment (as cited in [6] Hutchings, 2007, p. 245).

\section{Theme: The Multi-Functionality of the Internet's Applicability to Religion}

In Religion and the Internet, Hackett (2006) provides two valuable services for readers interested in CMCs and religion, one short and simple, the other wide ranging and diverse. First, she makes the simple but important distinction between "religion online" and "online religion." Crediting Lorne Dawson and Douglas Cowen for the definition, Hackett (2006) takes religion online to refer to "information about religion on the internet" whereas online religion she takes to refer to "religious experience or practice through the internet (p. 68) [7]."

Secondly, noting "the ambiguous, fluid, almost volatile" nature of the internet, as well as its composite character and combination of static and moving images and text, as well as aural and tactile forms of communication (that) lends it (the internet) an aura of mystery (Hackett, 2006, p. 68) [7]" she proceeds to set forth the myriad ways in which it (the internet) is used (functions) in religious applications. The following are representative of them.

\subsection{Communication}

Communication is the function most associated with the internet and it is this that draws most Christians to participate in CMCs. Hackett (2006) [7] notes that it is not primarily for information that Christians communicate on the web but rather for fellowship to "realize the body of Christ." Of course, fellowship goes beyond only information and requires some element of the personal. Though now common in the area of politics, Hackett (2006) [7] notes that some of the earliest religious use of the internet is by religiously persecuted groups. 


\subsection{Informing}

According to Hackett (2006), virtually all mainstream religions have recognized that credibility and even identity require use of the capacity of CMCs to "service their own communities and to supply key information to both members and non-members." She notes that the Vatican now has a comprehensive, multi-lingual website and that CMCs provide members and non-members with the new dimension of bloggers who then provide "electronically mediated religious news and opinions, or 'weblogs"” and also that podcasts of materials such as sermons are growing in popularity. According to Hackett (2006), "The appeal of these new personalized commentaries on world events lies in their spontaneity and alternative perspectives (p. 69) [7].”

\subsection{Learning}

This function makes religious knowledge that was previously esoteric available to all without hierarchical censorship and largely without cost. Websites such as [8] Beliefnet (www.beliefnet.com) provide large storehouses of facts, links and resources. Religious ritual information can be assessed at websites such as [9] orishanet.com (www.orishanet.com). Hackett (2006) cites writers such as Gunther et al., (2000), who describe the divide between those who welcome the democratization of religion being occasioned by the new accessibility of religious texts and information and those who "fear the subversion and loss of tradition that easy access to sacred knowledge may engender (p. 69) [7].”

\subsection{Experiencing}

Hackett (2006) argues that the internet facilitates new "possibilities of spiritual or religious experience." She suggests new forms of experience may be "absorption, asceticism, escapism, oneness, or communitas." She notes that religious experience can now be customized to "suit hectic, modern, work-oriented lifestyles (p. 70) [7]" offering the 10-minute spiritual exercises of Saint Ignatius of Loyola propounded by the Jesuits as an example. Finally, she asserts that the sense of oneness of believers can be enhanced as well as the connectedness between religious leaders and followers.

\subsection{Practicing}

Hackett (2006) makes the point that for certain alienated sectors of religious participants online worship includes less of a stigma and may be preferred to more formal worship. She suggests there is evidence that for youth, worship through the internet may be "the trend of the future" although she notes the finding of Goethals that suggests that "the internet cannot compete with the expressive and emotional power of live, or even broadcast, sermons (p. 70) [7]."

Hackett (2006) also makes the interesting point that for those religions that mandate ritual prescription requiring space that the internet can transcend both financial and physical constraints by providing "virtual" experiences. So, for example, Christians can walk the places of the cross in Jerusalem or Muslims make the Hajj via the technology of the internet. Hackett (2006) suggests that the "[p]ilgrimage is as much an act of the mind as an act of the body", and that simulating a pilgrimage online may also have beneficial effects for the supplicant (p. 71) [7]"

\subsection{Seeking}

Citing Stewart Hoover to the effect that personal autonomy is the most important trend in contemporary religion, Hackett (2006) argues that "the endless opportunities afforded by CMC make the internet seem like a gateway to paradise or a fast-track to nirvana." Noting that online religious seekers rival the number of online sex seekers, Hacket (2006) notes that $25 \%$ of all online surfers are religious surfers and explains that "(t)he hyper textual structure of the World Wide Web is conducive to seeking, with links that can take you on spiritual quests that condense both time and space (p. 71) [7].”

\subsection{Advocating}

To the extent that religions virtually are always concerned with some element of what Christians would call the "social gospel" the internet and CMCs provide a new and most efficient tool. Whether in the form of human 
rights, the environment, the sex trade, animal rights or other aspects of social concern, Hackett (2006) points out that there has been "exponential success using the CMC" to pursue these causes [7].

One can find an interfaith group advocating virtually any cause thought to be an outgrowth of one's religious beliefs and networking aspect of the internet is integral to any successful activism. Although there is a problem with access to CMCs on the part of repressed religious groups, Hackett (2006) notes that there is abundant evidence of them mobilizing their voice and cause through the internet, saying that "(i)t allows them to circumvent local or national forms of political, cultural or religious exclusion, and benefit from, not always uncritically, the discourses and mechanisms of international human rights (p. 71) [7].”

\subsection{Proselytizing}

Most people are aware that some religions avoid proselytizing (e.g., Judaism) and that others make proselytizing obligatory as part of religious doctrine (Christianity and Islam). Perhaps the most culturally relevant and interesting aspect of religious use of CMCs regards the CMC function of proselytizing. The issue of proselytizing presents a dilemma in that it presents the potential for religious based friction yet, at the same time, it constitutes a basic freedom in that it consists of the right to communicate and disseminate one's core beliefs.

Hackett (2006) asserts that this issue "is arguably the most controversial aspect of the right to freedom of religion and belief today" and that "(t)his is in part due to the influence of the modern media, not least the internet." She further suggests that the core of the problem is not merely proselytizing but that, it "is occurring in increasingly aggressive ways (p. 69) [7].”

According to Hackett (2006), Christian "cyber evangelists” employ not only hate speech but other methods of such types of "aggressiveness." One is what she calls a "bot" that he describes as "a floating, disembodied, pre-programmed text message (rather like a 'pop-up') that can be sent into chat rooms to deliver biblical verses and statements of faith-like a proselyte missile.” She further notes that (t)his naturally begs the question of how to counter uncivil and unsocial exploitations of CMCs within the context of fundamental freedoms of expression, religion and belief, and expectations of privacy (p. 69) [7]."

There are additional religious functions and applications of the internet mentioned in the Hackett (2006) analysis that are here omitted (e.g., the functions of healing, problem solving, and what he calls the "commodifying of the sacred") [7]. However, an examination of them reveals a striking similarity to issues regarding the functions of the internet as it relates to education in general. Some similar questions as well as similar effects arise in both the area of religion as well as education. Is the experience (religious experience as well as educational experience) valid or real? How does an essentially individual and solitary action become part of corporate action (worship in religion and collaboration in education)? Do CMCs unduly democratize that which is properly hierarchical? How does the new CMC version relate to the traditional version? My research regarding CMCs and religion in so many ways echoed issues that we studied throughout this semester with relation to education in general. Even the issue and challenge of proselytizing regarding religion was not dissimilar to the sensitivity issues involved in some educators' calls for real, earnest thick-skinned pursuit of truth in scholarly exchanges.

\section{Theme: The Social Shaping of Technology (Cultured Technology)}

Apparently groups do not avail themselves of technology such as CMCs in uniform and standardized ways. Instead, as a group's values become increasingly comprehensive and approach the level of a "world view" it "negotiates" the use or non-use of such technology through the lens of its values. It would be expected that of all groups religious groups would be likely to produce the integrated and comprehensive value systems productive of such world views. Therefore, this section focuses not so much as to how religious groups use CMCs as it does on the process by which they come to be used at all as well and how the process of using CMCs may affect the values of the religious group.

Discussion of this "negotiation" prompts examination of the ever present Heidi [10] Campbell (2005) who once again surfaces with a study entitled Spiritualising the internet: uncovering discourses and narratives of religious internet usage. In it she illustrates her application of the concept of social shaping of technology (SST) and the importance of discursive narratives in conceptualizing the internet for acceptable use.

Asserting that "(l)ittle theoretical work exists that provides frameworks for explaining online religious activities in terms of larger social and cultural processes" Campbell (2005) attempts to explain and illustrate the concept of social shaping of technology as well as to provide examples of how research that is conceptually similar 
is now proceeding regarding use of the internet by religious groups. In doing so she keeps the following questions foremost: Does the research involve the social and cultural process of "questions such as what (how)? Does a religious group's conception of the internet influence how they negotiate its use and what (how)? Do these perceptions link to trends in contemporary society and the role of religion in culture as a whole (p. 1) [10]?”

[10] Campbell (2005) begins by describing the nature of the concept of Social Structuring of Technology (SST) and provides an example of it. Thereafter she discusses four common discourses used by religious internet users to conceive of and describe the internet and their four corresponding narratives of the religious internet that can produce what she calls the "spiritualizing of the internet framing process." Finally, she illustrates the process she has explained within the context of two other studies that focused in similar ways on religiously conservative Jewish groups in Israel and how they negotiated culturally (religiously) acceptable responses to internet use.

Challenging the notion that technology is wholly determinative, [10] Campbell (2005) explains that the social shaping of technology views technology as the product of the interplay between technical and social factors and that as a social process it is possible for different social groups to shape technology differently so as to achieve compatibility with their own values and to reinforce the typical religious patterns of the group. Noting that a variety of approaches employ this concept, Campbell (2005) then proceeds to illustrate one of them known as "domestication" to show how technology has been adapted into the social life of a group as a means of survival by citing a study by [11] Umble (1992) on Amish use of the telephone.

In the study religious users of telephone technology "domesticated" and thereby made its use socially acceptable by redefining it as a "communal device" shared and located in central locations. In so doing, they re-framed or shaped the technology as a functional survival device compatible with their values rather than seeing it as they had previously as a frivolous and secularizing device incompatible with their values. The effect of this social negotiation, allowed them, according to Campbell (2005), to "reconstruct technology by situating it in the community, thus allowing use while still affirming their values about maintaining distance from secular society” and shows how "(t)he domestication approach highlights how a particular group can tame a technology to fit into a particular social or even religiously cultured space (p. 4) [10].”

Having explained the process of social shaping of technology and given an example of it, Campbell (2005) notes that "What I am most concerned with in this paper is how traditional religious groups are influenced by new media technology and how they negotiate technological interaction with their religious beliefs...” and asserts that

The choices of religious users about technology, especially those within traditional religions (such as Islam, Christianity, Judaism), are negotiated through different ways than those within other social groups. This is because choices within religious groups are guided not just by needs and desires, but occur within the framework of a distinct worldview laden with spiritual meanings and values (p. 5) [10].

For this reason she contends that "examination of how technology and religious users are being studied outside SST (socially shaped technology) must be considered in order to move closer to understanding the religious shaping of technology [10] (Campbell, 2005, p. 4) [10]” and therefore turns to an examination of two ultra-conservative Jewish groups and their use of CMCs in order to better understand their religious shaping of technology. In both of these groups shaping of technology takes place, in one through linguistic discourse and in the other through a re-definition of social needs.

In a study by Livio, Oren \& Keren Tenenboim (2004), Campbell (2005), after explaining that the ultra-Orthodox Jewish group under study viewed the internet as subversive of group values yet needed it for economic survival, identified four discursive strategies that women of the group used to legitimize the internet. These included "framing the Internet in binary opposition in order to distinguish the technology from the content, separating personal and societal effects, drawing on acceptable justifications such as statements of religious officials... or depoliticizing use by denying subversive implication of the technology (Campbell, p. 6).” Through the use of these discursive strategies the study revealed how the women framed the internet as being compatible with community (group) values and thereby became justified in working at home. Campbell's (2005) conclusion regarding the study was that:

Discursive framing strategies served an important role within the community, both framing public use and 
satisfying cognitive dissonance within many members about the danger of this technology. Language became a powerful tool for making a technology that was considered secular, acceptable within certain boundaries (p. 7).

A second example of religious group social shaping regarding internet use offered by [10] Campbell (2005) is a study by [12] Barzilai, \& Barzilai-Nahon (2004). Again this study centered on an ultra-Orthodox Jewish group in Israel whose religious beliefs prohibited use of the internet but who, for practical, economic purposes had need of its use. Again, [10] Campbell (2005) observes that the group "negotiated" use of the internet but that in this case its negotiation consisted of redefining the nature of the internet in order to make it compatible with group values. In this case, the previously suspect, secular laced internet was redefined as a type of religious tool, one that could "encourage traditional forms of communication, such as Responsa online... accessing sermons, news and facilitating religious argumentation (p. 7).”

[10] Campbell (2005) notes that for [12] Barzilai and Barzilai-Nahon (2004), discourses that recognize that religious cultural spaces are affected by both complex social and distinct value-construction processes become what they termed "cultured technology" and Campbell (2005) holds that "(t)he extent to which a religious group can culture a technology, such as the Internet, indicates the extent to which it can be incorporated into the community and provide opportunities for group or self expression within these boundaries (p. 7).”

The concept of social shaping of technology and its corollary of cultured technology both seem self-evident yet the details of the shaping or culturing are important. No doubt all value laden groups engage in a similar process and just as in the case of religious users they both change the definition of the technology and are changed by their resultant use of it. I have been told of religious groups that exist today in the US that forbade even radio use 50 years ago but because of the need of agricultural information (e.g., weather forecasts) redefined the radio from "secularizing” to "productive.” Today the descendants of these groups use not only the radio but also its communicative descendants, television and the internet. Apparently it is a short distance from weather reports to global warming. Although religious groups apparently envision bending CMCs to their ends it appears that, with time, the effect can be reciprocal. My examination of CMCs and how religious groups shape the technology raised questions for me about how educational institutions may be similarly redefining technology and the impact upon educational values of such redefinitions.

\section{Theme: Religious Authority and Power Relationships in the Online Environment}

[12] Barzali-Nahon \& Barzali, (2004) suggest that hierarchy is one of the characteristics of conservative religious groups. In her study, Who’s Got the Power? [13] Campbell (2007) seeks to discover what happens to religious authority and power relationships within the context of online environments.

Seeking to offer a more concrete definition of authority by situating it within a concept of multiple layers of authority, she examines and compares interviews with three religious groups (Islam, Christianity, and Judaism) as a basis for making more informed claims regarding the impact of the internet on religious authority.

To make her approach to questions of authority more concrete, Campbell (2007) focuses on what she calls multiple layers of authority and attempts to connect the concept of authority to one of four layers: hierarchy, structure, ideology, or text. To do so she asks questions about authority such as:

Is it the power position of traditional religious leaders?

Is it the established systems by which policy decisions are made and information is passed on to community members?

Is it the corporate ideology of the community?

Is it the role and interpretation of official religious rhetoric and teaching (p. 1044) [13]?

In so doing, she sought to do more than merely assert that the internet transforms or challenges traditional authority; but rather, to be able to identify the specific form or type of authority that it affects.

Finding previous research to be unsystematic as well as unspecific regarding use of the term "authority", Campbell (2007) resorts to the classic work of Max Webber to define authority. Quoting Weber to the effect that "it is useful to classify the types of authority according to the kind of claim to legitimacy typically made by each" she distills the following three kinds of legitimate authority:

1) Legal authority where "loyalty is given to a legally established impersonal order." 
2) Traditional authority where "obedience is given to the person who occupies traditionally sanctioned position of authority."

3) Charismatic authority where authority is "based on devotion to an individual who exhibits a particular characteristic, ideal, or exemplary quality that motivates others to adhere to the normative patterns sanctioned by that individual (pp. 1044-1046) [13].

Having established the above framework by which to consider the topic of authority in religion online, [13] Campbell (2007) then proceeded to use her four part format to examine and compare interviews with believers in the three major mono-theistic religions by way of a qualitative thematic analysis. Inasmuch as the interviewees in each religious group varied in their ratio of conservative to liberal and inasmuch as the Islamic group consisted disproportionately of Sufi Muslims (a very small and non-representative division of the Muslim world) the findings have less of a predictive than representational value. Nonetheless the following reflects her interesting findings:

\subsection{Religious Hierarchy}

In discussing the role of religious leaders (Imam, Rabbi \& Cleric), there appears to be a significant divide. The practicing Jews and Muslims gave significant weight to pronouncements by their leaders regarding religious knowledge and practice whereas the non-practicing Jews and Christians were described as "more apt to reflect critically on the role and influence of religious authority figures on community belief or the practices they advocated, especially in relation to the internet [13] (Campbell, 2007, p. 1055).” Campbell (2007) notes that this finding suggests a need for further research regarding the effect of online religion on leaders' authority status.

\subsection{Religious Structures}

In discussing systems of community practice such as manner of worship, following of codes of practice, ways of passing information and remaining connected, Campbell (2007) found that the Christians emphasized some relations that suggested they valued the online relations more highly than those of the organizational church. Though structures of the organizational church were seen as necessary, Campbell (2007) reports that "they were also described as a hindrance to social connectivity (p. 1056) [13].” Furthermore, Campbell (2007) reports that though the internet was seen as a tool that served to make the authority structure of the church more transparent, "it was the social and spiritual network of the Church as created through the Internet that seemed to be the more valued structure (p. 1056) [13]."

On the other hand, the Jewish interviewees tended to emphasize "the role the Jewish community plays in creating and maintaining certain systems and discourses." In other words, it is the community that exercises authority or as [13] Campbell (2007) says, "Interpretation of certain texts or beliefs is not to be done by the individuals but rather agreed upon and then accepted by the community." The effect is that here the "religious structure refers to the community structure, or how the religious community sets standards and dictates certain modes of interaction or belief (p. 1056). [13]"

Strangely, the Muslim responses appear to have been insufficient to merit note by Campbell (2007) on this measurement.

\subsection{Religious Ideology}

On this criterion all three groups tended to discuss authority by focusing on some image of a single or global community such as "community of one voice" or the "global body of Christ" or the "Straight Path." For the Jewish interviewees, the idea of community affiliation also signifies participation in the ideas of the community. For the Christian interviewees there was emphasis on trying to link the local church to the ideas of the global church. Finally, for the Muslim interviewees, as was the case with the Christian, there was evidence that local authority was affected by an emphasis on global community or structures over local ones.

\subsection{Religious Texts}

The authority of religious texts received the smallest response on all criteria except for the Muslims who made numerous references to the Koran as a source of authority. Strangely again, Campbell (2007) says little about this but instead closes the article by noting only that online authority and texts need additional research along the 
lines of the following questions:

Are religious texts cited as sources of truth or community policy as frequently and in the same ways in online religious community conversation as in similar religious offline groups? Are texts affirmed or criticized online with the same consistency as they are offline? And do the same texts serve the same roles in both contexts (p. 1058) [13]?

\section{Theme: Considerations in the Migration of Religions Online}

My last step in traversing the wide but shallow stream of religions and CMCs recommends a series of articles collectively called: Cross-Cultural Perspectives on Religion and Computer Mediated Communication by [14] Ess, Kawabata, \& Kurosaki, (2007). Consisting of ten articles focusing on a wide range of religions from monotheistic, to polytheistic, to philosophical, in various national settings, it coheres around the question of the scope and degree of migration online of each of the religions as well as the factors that hinder or encourage their online migration. The articles collectively raise and discuss aspects impacting the likelihood of different believers utilizing the internet. In some ways the issue mimics consideration of what types of students might migrate toward the online educational experience. Together they flesh out some of the following determinants of religious online participation:

The articles pierce the perception that the dependency of modern religions upon the communication technology of print and literacy preclude their migration to the "secondary orality" of the internet. Instead the articles reflect that "This medium (the web) has been embraced by most of the world religious traditions, to the point that not having Internet representation is a rarity for a religious organization, even if it is luddite in its beliefs and practices [14] (Ess et al., 2007, p. 941).”

Insofar as the previously mentioned concepts of Social Shaping of Technology and Cultured Technology there appear to be numerous religions that have demonstrated the capability to transform CMC technology and to largely avoid being themselves transformed.

Not every religious tradition has come to embrace the Internet and CMCs with equal and unequivocal enthusiasm and there are "specific characteristics of believers and traditions foster resistance to migration online." For example, certain Japanese Buddhist as well as Anglican Christian traditions that are more rigidly hierarchical than others resist migration online. The same is true of some types of Islam that place very strong "emphasis on the role of the Qur'an as a sacred text [14] (Ess et al., p. 942).”

Some evidence suggests an online migration that tends to be one-way may be the result of the approach to their sacred text by Roman Catholics Christians.

Some evidences exist that strong distinctions between the secular and the sacred may have the effect of precluding some types of religious practices from being comfortably presented via the internet. The authors give the example of tantric practices. I assume another example might be the Christian Eucharist.

In some national instances (e.g., Japan and Singapore) migration of a religion online may be more a function of demographics, with religions largely comprised of older believers being less likely to avail themselves of online technology, than of religious characteristics.

Finally, religions comprised of Diaspora members or persecuted minorities may be more likely to migrate online because of these characteristics rather than because of the characteristics inherent in their religion.

\section{Conclusions}

Though of relatively recent origin, the field of religion and CMCs appears to this reviewer to be advancing rapidly - in all directions! Whether the question is CMCs use by religious leadership [15] (Wyche et al., 2006), the challenge of a new version of religious imperialism [3] (Kong, 2001), the correlation relationship between religiosity and use of CMCs [16] (Armfield \& Holbert, 2003), the philosophic impact of moving from the primarily aural word to the sight orientated printed word to the present "sensorium" of Org's "secondary orality [17] (O’Leary, 1996, p. 784)" or CMCs as adapted to almost any of the major traditional religions, they have all been visited by significant research.

Though viewed by some religious leaders as utopian and by others as dystopian, there can be little doubt that CMCs have great impact on the human practice of religion. Stephen O’Leary (1996), describing the new form of "secondary orality" of the internet said "(w)ith this new medium, aspects of orality and literacy are combined into a new, hybrid form of communication that, in the words of one net-worker, is both talking and writing yet 
isn't completely either one (p. 786) [17].” Though its impact remains to be seen, there is little doubt as to its continued evolution. There is no stemming its continued growth. Campbell (2003) quotes Mello to the effect that: "Religious groups that remain outside the internet communication revolution will become like ghettoes, like some Puritan communities in the eighteenth and nineteenth centuries, who tried to halt the message of time to preserve tradition...Changes (religious) arising from computer technology are irreversible (p. 213) [5].”

The continued evolution of the relation of CMCs and religion problematizes the "believer" of the future. For Christians perhaps the only safe course for the believer is the "message/media" prescription of the [18] Pontifical council for Social Communications of the Catholic Church. It prescribes:

Reflecting on the Internet, as upon all the other media of social communications, we recall that Christ is "the perfect communicator"- the norm and model of the Church’s approach to communication, as well as the content that the Church is obliged to communicate (Pontifical Council for Social Communications, “The Church and Internet”, 2002).

\section{References}

[1] Chama, J.R.C. (1996) Finding God on the Web. Time, 149, 52-59.

[2] Campbell, H. (2005) Making Space for Religion in Internet Studies. The Information Society, 21, 309-315. http://dx.doi.org/10.1080/01972240591007625

[3] Kong, L. (2001) Religion and Technology: Refiguring Place, Space, Identity and Community. Area, 33, 404-413. http://dx.doi.org/10.1111/1475-4762.00046

[4] Wilson, W. (2000) The Internet Church. Word, Nashville.

[5] Campbell, H. (2003) Approaches to Religious in Computer-Mediated Communication. In: Mitchell, J.P. and Marriage, S., Eds., Mediating Religion: Conversations in Media, Religion and Culture, T \& T Clark, London, 213-228.

[6] Hutchings, T. (2007) Creating Church Online: A Case-Study Approach to Religious Experience. Studies in World Christianity, 13, 243-260. http://dx.doi.org/10.3366/swc.2007.13.3.243

[7] Hackett, R.I.J. (2006) Religion and the Internet. Diogenes, 211, 67-76. http://dx.doi.org/10.1177/0392192106069015

[8] Beliefne (2015) Inspiration. Spirituality. Faith. http://www.beliefnet.com/

[9] (2015). www.orishanet.com

[10] Campbell, H. (2005) Spiritualising the Internet Uncovering Discourses and Narratives of Religious Internet Usage. Heidelberg Journal of Religions on the Internet, 1, 1-26.

[11] Umble, D.Z. (1992) The Amish and the Telephone: Resistance and Reconstruction. In: Silverstone, R. and Hirsch, E. Eds., Consuming Technologies: Media and Information in Domestic Spaces, Routledge, London, 183-194. http://dx.doi.org/10.4324/9780203401491_chapter_11

[12] Barzilai-Nahon, K. and Barzilai, G. (2004) Cultured Technology: Internet and Religious Fundamentalism. The Information Society, 21, 1-35.

[13] Campbell, H. (2007) Who's Got the Power? Religious Authority and the Internet. Journal of Computer-Mediated Communication, 12, 1043-1062. http://dx.doi.org/10.1111/j.1083-6101.2007.00362.x

[14] Ess, C., Kawabata, A. and Kurosaki, H. (2007) Cross-Cultural Perspectives on Religion and Computer-Mediated Communication. Journal of Computer-Mediated Communication, 12, 939-955. http://dx.doi.org/10.1111/j.1083-6101.2007.00357.x

[15] Wyche, S.P., Hayes, G.R., Harvel, L.D. and Grinter, R.E. (2006) Technology in Spiritual Formation: An Exploratory Study of Computer Mediated Religious Communications. Proceedings of the 2006 20th Anniversary Conference on Computer Supported Cooperative Work, 199-208.

[16] Armfield, G.G. and Holbert, R.L. (2003) The Relationship between Religiosity and Internet Use. Journal of Media and Religion, 2, 129-144. http://dx.doi.org/10.1207/S15328415JMR0203_01

[17] O’Leary, S.D. (1996) Cyberspace as Sacred Space: Communicating Religion on Computer Networks. Journal of the American Academy of Religion, 64, 781-808. http://dx.doi.org/10.1093/jaarel/LXIV.4.781

[18] Pontifical Council for Social Communications (2002) The Church and Internet. http://www.vatican.va/roman_curia/pontifical_councils/pccs/documents/rc_pc_pccs_doc_20020228_church-internet_e n.html\#RECOMMENDATIONS 
Scientific Research Publishing (SCIRP) is one of the largest Open Access journal publishers. It is currently publishing more than 200 open access, online, peer-reviewed journals covering a wide range of academic disciplines. SCIRP serves the worldwide academic communities and contributes to the progress and application of science with its publication.

Other selected journals from SCIRP are listed as below. Submit your manuscript to us via either submit@scirp.org or Online Submission Portal.
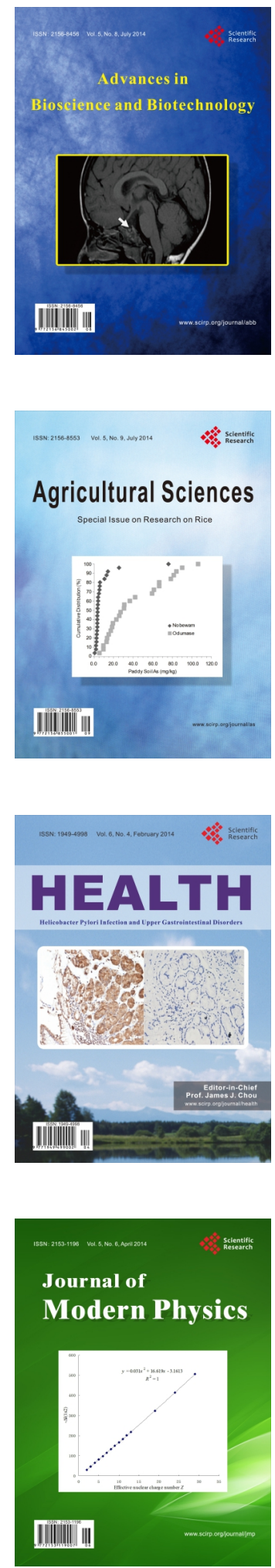
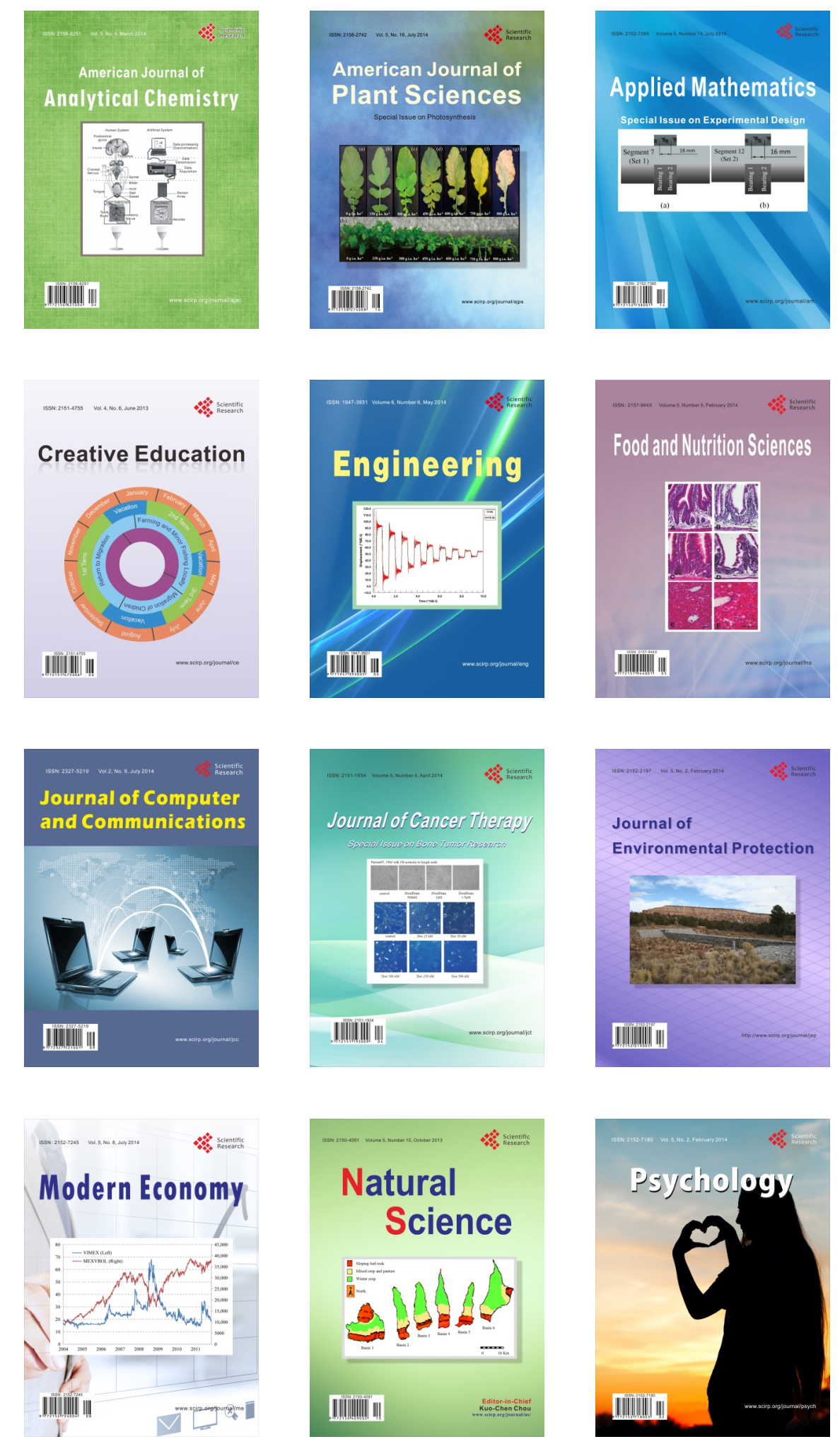